\section{Kastamonu Eğitim Dergisi Kastamonu Education Journal}

Mart 2019 Cilt:27 Sayı:2

kefdergi.kastamonu.edu.tr
Başvuru Tarihi/Received: 14.02 .2018

Kabul Tarihi/Accepted: 08.05.2018

DOI: $10.24106 /$ kefdergi.2687

\title{
Mesleki Müzik Eğitimi Alan Öğrencilerin Düşünme Stilleri ile Çeşitli Değişkenler Arasındaki İlişkinin İncelenmesi
}

\section{Examining the Relationship Between the Thinking Styles and Some Demographical Variables of the Students Receiving Professional Music Education}

\section{Öz}

\author{
Şevki Özer AKÇAY ${ }^{1}$
}

Düşünme stilleri öğrenmeye etki eden unsurlardan biri olarak kabul edilmektedir. Buradan hareketle mesleki müzik eğitimi alan üniversite öğrencilerinin düşünme stillerinin belirlenmesi ve bu stillerle çeşitli demografik değişkenler arasındaki ilişkinin incelenmesi amacıyla yapılan bu çalışma; Atatürk Üniversitesi Güzel Sanatlar Fakültesi'nde lisans düzeyinde mesleki müzik eğitimi almakta olan 94 öğrenci ile yürütülmüştür. Araştırmanın verileri Sternberg ve Wagner (1991) tarafindan geliştirilen ve Fer (2005) tarafindan Türkçe'ye çevrilerek geçerliği ve güvenirliği yapılmış olan “Düşünme Stilleri Envanteri” nin yanında araştırmacı tarafindan geliştirilen kişisel bilgi formu kullanılarak elde edilmiştir. Düşünme stilleri envanteri ve kişisel bilgi formu ile elde edilen veriler tek yönlü varyans analizi (ANOVA), Tukey HSD testi ve betimleyici istatistiki teknikler kullanılarak analiz edilmiştir.

Elde edilen bulgulara bakıldığında çalışma grubunun genel olarak Yasamacı, Yürütmeci, Yargılayıcı, Hiyerarşik, Dışsal ve Liberal düşünme stillerine daha yüksek düzeyde sahip oldukları görülmüştür. Düşünme stilleri envanterinden elde edilen alt ölçek ortalamalarının, cinsiyete göre bazı farklılıklar göstermekle birlikte genelde orta düzeyin üzerinde olduğu; kadınlarda en yüksek ortalamanın Monarşik düşünme stili alt boyutunda görülürken erkeklerde ise en yüksek ortalamanın Yasamacı düşünme stili alt boyutunda olduğu görülmektedir. Düşünme stillerinin sınıf düzeyine göre durumuna bakıldığında 2. sınıf öğrencilerinin Yasamacı düşünme stiline, 4. sınıf öğrencilerinin ise Yasamacı, Bütünsel ve Ayrıntısal düşünme stillerine daha yüksek düzeyde sahip oldukları görülmüştür. Güzel Sanatlar Liseleri dışında kalan diğer liselerden mezun olan öğrencilerin Yasamacı, Yürütmeci, Yargılayıcı, Hiyerarşik ve Liberal düşünme stilleri puan ortalamalarının Güzel Sanatlar Liselerinden mezun olan öğrencilere göre daha yüksek olduğu görülmüştür. Öğrencilerin AGNO (Ağırlıklı Genel Not Ortalaması) düzeyi ve bireysel çalgı değişkenlerine göre düşünme stillerinde anlamlı farklılıklar olmadığı belirlenmiştir.

Anahtar Kelimeler: Düşünme stilleri, mesleki müzik eğitimi, müzik, müzik eğitimi.

\section{Abstract}

Thinking styles are considered as one of the elements that affect learning. In this context, this study was conducted with 94 students who studied at Atatürk University, Faculty of Fine Arts, at Undergraduate Level to determine the thinking styles of the university students who receive professional music education; and to investigate the relation between these styles and various demographical variables. The data of the study were collected by using the "Thinking Styles Inventory". The inventory was developed by Sternberg and Wagner (1991) and was translated into Turkish by Fer (2005). Its reliability and validity studies were conducted. The Personal Information Form, which was developed by the author of the study, was also used to collect the data in the present study. The data that were collected by using the Thinking Styles Inventory and the Personal Information Form were analyzed by using the One-Way Variance Analysis (ANOVA), Tukey HSD test, and descriptive-statistical techniques.

When the findings were analyzed it was observed that the Study Group generally had the Legislator, Executive, Judgmental, Hierarchical, External and Innovative Thinking Styles at higher levels. It was determined that the averages of the sub-scales of the Thinking Styles Inventory varied according to gender; however, these averages were generally above the medium level, and the highest average in women was detected in Monarchic Thinking Style sub-dimension while the highest average was detected in men in the Legislative Thinking Style sub-dimension. When the thinking styles were analyzed in terms of grades of the students it was observed that $2^{\text {nd }}$ graders had mostly the Legislative Thinking Style; and $4^{\text {th }}$ graders had the Legislative, Holistic and Local Thinking Styles at higher levels. It was also determined in the study that the average scores at Legislative, Executive, Judgmental, Hierarchical and Innovative Thinking Styles of the students, who were graduated from high schools other than Fine Arts High Schools, were higher than those who were graduated from Fine Arts High Schools. It was observed that there were no significant differences in the thinking styles of the students at the WGPA (Weighted Grade Point Average) level and Individual Instrument variables.

Keywords: Music, music education, professional music education, thinking styles.

1. Atatürk Üniversitesi Güzel Sanatlar Fakültesi Müzik Bilimleri Bölümü, Erzurum, Türkiye; https://orcid.org/0000-0002-0493-9897

Atıf / Citation: Akçay, Ş.Ö. (2019). Mesleki müzik eğitimi alan öğrencilerin düşünme stilleri ile çeşitli değişkenler arasındaki ilişkinin incelenmesi.Kastamonu Education Journal, 27(2), 683-700. doi:10.24106/kefdergi.2687 


\section{Extended Summary}

The common elements in the definitions of many educationalists made according to various approaches are the interaction with the environment, information and experiences acquired as a result of this interaction, and the permanent changes that appear in the own life of the individual. Based on the fact that there is no single accurate approach about learning, it is possible to claim that success occurs with the use of many different approaches in an efficient manner. The important thing is that the individual notices the most suitable methods for him/her which ensures that the desired content is learnt in the best way. The individual may perform a more efficient learning by using one or several of these methods. In this context, it is also possible to talk about a way of thinking of the individual, or in other words, a thinking style. Learning is associated with thinking, and when the individual organizes thinking, s/he will use the way s/he prefers in learning activities (Cano-García and Hughes, 2000). In fields like psychology and education, the concept "style" is used to describe the thinking, learning and teaching forms, and is defined as the differences that affect human performance. As a result of the studies conducted on styles, various style types or hypotheses have emerged with different models.

"Thinking Styles", which are among the cognition-focused mental styles, are based on the Mental Self-Management Hypothesis, and was developed by Sternberg $(1988,1997,2009)$. The basis of the hypothesis consists of the reflection of the mind of the individual, which organizes thinking, to the outer world. The "Thinking Styles", which are based on this hypothesis, denotes the way in which people prefer and choose to use their mental skills and knowledge. In actual fact, individuals have a profile which consists not only of one single style but consists of many different styles. People either adopt the job to their styles, or adopt their styles to their jobs when they are doing something. Individuals may not prefer the style which they have used previously for one certain job in doing another job. These styles may vary according to the job, target, the limits of the resources, and the age, culture and gender of the individual.

In organizing education-teaching activities, in the preparation and application of the programs, and in re-organization of these programs according to needs, the related needs must be defined well, and the individuals that will be assigned with relevant activities must be known. In this context, we believe that the elements that will affect the learning of teachers who will be direct targets of educational activities must be known, and the relations between these variables must be analyzed well, which will affect the efficacy of education. Thinking styles are considered as one of the elements that affect learning. In this context, this study was conducted with 94 students who studied at Atatürk University, Faculty of Fine Arts, at Undergraduate Level to determine the thinking styles of the university students who receive professional music education; and to investigate the relation between these styles and various demographical variables. The data of the study were collected by using the "Thinking Styles Inventory". The inventory was developed by Sternberg and Wagner (1991) and was translated into Turkish by Fer (2005). Its reliability and validity studies were conducted. The Personal Information Form, which was developed by the author of the study, was also used to collect the data in the present study. The data that were collected by using the Thinking Styles Inventory and the Personal Information Form were analyzed by using the One-Way Variance Analysis (ANOVA), Tukey HSD test, and descriptive-statistical techniques.

Some of the findings obtained as a result of the study were consistent with the literature while some of them conflicted with it. When the findings were analyzed it was observed that the Study Group generally had the Legislator, Executive, Judgmental, Hierarchical, External and Innovative Thinking Styles at higher levels. It was determined that the averages of the sub-scales of the Thinking Styles Inventory varied according to gender; however, these averages were generally above the medium level, and the highest average in women was detected in Monarchic Thinking Style sub-dimension while the highest average was detected in men in the Legislative Thinking Style sub-dimension. When the thinking styles were analyzed in terms of grades of the students it was observed that $2^{\text {nd }}$ graders had mostly the Legislative Thinking Style; and $4^{\text {th }}$ graders had the Legislative, Holistic and Local Thinking Styles at higher levels. It was also determined in the study that the average scores at Legislative, Executive, Judgmental, Hierarchical and Innovative Thinking Styles of the students, who were graduated from high schools other than Fine Arts High Schools, were higher than those who were graduated from Fine Arts High Schools. It was observed that there were no significant differences in the thinking styles of the students at the WGPA (Weighted Grade Point Average) level and Individual Instrument variables. 


\section{Giriş}

İngilizcede belirli bir kişi, grup, mekân ya da dönem için bir şeyler yapmanın tipik bir yolu (Cambridge, 2007) anlamına gelen stil sözcüğünün Türkçedeki sözlük tanımı "üslup, biçem” şeklindedir (Türk Dil Kurumu [TDK], 2016). Bir başka tanıma göre stil, yapılan, yazılan, üretilen ya da söylenen herhangi bir şeydeki ayırt ediciliktir. Aynı zamanda stil resim, müzik, mimari ve edebiyatta ya da bir kişinin bir işi yapmadaki kendine özgü karakteri olarak da tanımlanabilir (Webster, 1993). Buradaki kişiye özgülük bir jimnastikçinin zarafetini, bir futbolcunun oyununu, bir müzisyenin yorumculuğunu betimlemek için kullanılabilir. Bununla birlikte psikoloji ve eğitim gibi alanlarda stil kavramı düşünme, öğrenme, öğretme şekillerini betimlemek için kullanılmaktadır (Esmer, 2013). Zhang (2000a) stil kavramını insan performansını etkileyen farklııklar olarak tanımlamaktadır. Stil, yetenek ile kişilik arasında bir bağlantıdır; bireyin yeteneklerini kullanmadaki tercihi, bilgi ve becerisini uygularken kullanmayı tercih ettiği yoldur. Başka bir ifadeyle stil, bireylerin bir çalışmayı, projeyi, işi yapmayı düşünürken ya da yaparken kullanmayı tercih ettikleri yoldur (Sternberg, 1988, 1997 ve 2009; Zhang, 2000a).

Öğrenme, en yalın haliyle, bireyin çevresiyle kurduğu iletişim ve etkileşim sonucunda oluşan ve bireyin davranışlarında değişikliğe yol açan bir süreç olarak tanımlanabilir (Güven, 2013). Bir başka deyişle öğrenme, yaşant ürünü ve az çok kalıcı izli davranış değişikliğidir (Demirel, 2014). Başka bir tanıma göre öğrenme, davranışlarda ya da öğrenilmiş biçimde davranabilme kapasitesinde meydana gelen ve pratikten, deneyimin diğer şekillerine kadar çeşitli alanlarda sonuç veren kalııı bir değişikliktir (Schunk, 2011). Pek çok eğitim bilimci tarafindan çeşitli yaklaşımlara göre yapılan öğrenme tanımlarında ortak olan temel öğeler çevreyle olan etkileşim, bu etkileşim sonucu elde edilen bilgi ve deneyimler, bireyin kendi yaşantısında ortaya çıkan kalıcı değişikliklerdir. Öğrenmeyle ilgili tek bir doğru yaklaşım olmamasından hareketle başarının çok farklı stillerin etkili biçimde kullanılmasıyla gerçekleştiği söylenebilir. Önemli olan bireyin öğrenmek istediği içeriği en iyi şekilde öğrenebilmesini sağlayacak olan, kendine en uygun yolların farkında olmasıdır. Birey bu algılama yollarından bir ya da birkaçını kullandığı bir stil profili oluşturarak daha etkili bir öğrenme gerçekleştirebilir.

Günümüzde eğitim alanı, bireylerin davranışları kadar duyuş ve düşünüşünde de bazı değişimleri hedeflemektedir. Bunu yaparken kişinin kendine özgü potansiyelini ortaya çıkarabileceği öğrenme ortamlarını desteklemekte ve kişinin öğrenme yolunu yapılandırmasına olanak tanımaktadır. İnsan zihninin sahip olduğu çeşitlilik ve her beynin kendine özgü bir yapıya sahip olması bireyler arasında farklı öğrenme yollarının tercih edilmesine sebep olmaktadır (Esmer, 2013). Kişinin bilgiyi işlemede ve verilen görevle ilgilenmede tercih ettiği yol (Zhang \& Sternberg, 2005 ve 2006) olarak tanımlanan zihinsel stiller (intellectual styles) de bireysel farklıklar içinde yapılandırımış önemli ve gelişmeye açık bir çalışma alanıdır. Öğrenmek de düşünmeyle ilişkilidir ve kişi düşünmeyi organize ederken tercih ettiği yolu öğrenme eyleminde de kullanacaktır (Cano-García \& Hughes, 2000). Dolayısıyla "zihinsel stil" kavramı düşünme stilleri, öğrenme stilleri, karar verme ve problem çözme stilleri gibi, alan yazında stil sözcüğüyle birlikte kullanılan pek çok kavramı kapsayacak şekilde kullanılmakta ve yetenek ya da benlik olarak değil, bu ikisi arasında yer alan arayüz olarak görülmektedir (Zhang \& Sternberg, 2006). Özellikle eğitimin en önemli paydaşlarından biri olan öğretmen adaylarının zihinsel stil tercihlerini bilmeleri ve bu tercihlerini işe uygun olarak kullanabilme becerisini kazanmaları oldukça önemlidir. Esnek olmayan ya da işe göre değişmeyen bir stil tercihinin üretkenliği ve mesleki beceriyi de olumsuz yönde etkileyebileceği düşünülebilir (Esmer, 2013).

Stiller üzerine yapılan araştırmalar sonucunda, her biri farklı modellere sahip çeşitli stil türleri ya da kuramları ortaya çıkmıştır. Stil modelleri arasında ortak özellikler olduğu gibi stil yaklaşımları ve kuramsal dayanaklar açısından bazı farklılıklar da görülmektedir. Stil sınıflamaları genellikle bu benzerlik ve farklılıklar irdelenerek yapılandııımıştır. Literatürde yaygın olarak kullanılan kapsamlı bir sınıflandırma Sternberg ve Grigorenko (Sternberg, 1997, 2009; Sternberg \& Grigorenko 1997) tarafindan yapılmıştır. Bu çalışmalarda stiller, biliş odaklı yaklaşım (cognition centered approach), kişilik odaklı yaklaşım (personality centered approach) ve etkinlik odaklı yaklaşım (activity-centered approach) olmak üzere üç başlık altında toplanmışlardır. Bu sınıflandırmada biliş odaklı yaklaşım bilişsel stiller, etkinlik odaklı yaklaşım da öğrenme stilleri olarak bilinmektedir (Esmer, 2013).

Biliş odaklı zihinsel stillerden düşünme stilleri Sternberg (1988, 1997 ve 2009) tarafindan geliştirilen “Zihinsel Öz-Yönetim Kuramı"na dayanmaktadır. Kuramın temelini, düşünmeyi organize eden birey zihninin dış dünyaya yansıma biçimi oluşturur. Kurama dayalı olan "Düşünme Stili" ise insanların zihin ve bilgilerini kullanmak için seçtikleri, düşünmeyi tercih ettikleri yoldur. Kurama göre zeka ya da yetenek olmayan düşünme stili, zekanın ya da yeteneğin kullanılma yoludur. Pratik olarak yeteneklerinde benzer olanlar dahi farklı stillere sahiptir. Aslında bireyler tek bir stile değil, stillerden oluşan bir profile sahiptir. Bireyler bir işi yaparken ya işi stillerine ya da stillerini işe uyumlu hale getirirler. Bireyler bir işte tercih ettikleri stili başka bir işte tercih etmeyebilirler. Stiller göreve, hedeflere, kaynakların sınırlarına, bireyin yaşına göre değişiklik gösterebilir. Bireyin sahip olduğu düşünme stili bir ölçüde sosyalleşebilir; bir dereceye kadar bi- 
reyin yaşadığı çevre ile etkileşime girerek değişebilir. Stiller öğrenilebilir ve geliştirilebilir; okul, ev, iş, sosyal yaşam gibi yaşamın çeşitli alanlarında kullanılabilir (Sternberg, 1988, 1997 ve 2009; Zhang \& Sternberg, 2000).

Zihinsel özyönetim kuramının temel özellikleri şöyle özetlenebilir: (1) Tek değil, beş boyut altında 13 düşünme stilini açıklamaya yönelir. (2) Tek bir stil yerine, bireyin stillerinin profili üzerinde durur. (3) Stiller, iyi ya da kötü olarak sınıflanmaz, çünkü stil tercihi, bireyin yaptığı iş ile etkileşimini içerir. (4) ikili karşıtlık (dichotomous) yerine, süreklilik (continua) gösterir (Sternberg, 1988, 1997 ve 2009). Bu araştırmada kullanılan ve Sternberg'in “Zihinsel Özyönetim Kuramı"na dayalı olarak Sternberg \& Wagner (1991) tarafindan geliştirilen, 5 temel boyut altında 13 alt ölçeği bulunan düşünme stillerinin (Sternberg, 1988, 1997 ve 2009; Zhang, 2002) ana özellikleri aşağıda sunulmuştur.

\section{I. İşgörüler (Functions)}

1. Yasamacı (Legistlative): Yenilikçi, yaratıcı, fikir üreten, işleri kendi bildikleri gibi yapmayı seven, kendi kurallarını kendileri koymaktan hoşlanan. Bu stile sahip öğrenciler aldıkları eğitimi eleştirme eğilimindedirler. Meslek olarak yazar, şair, besteci, ressam, bilim insanı, kâşif, moda tasarımcısı, politika yapıcı, girişimci vb. olmayı tercih ederler.

2. Yürütmeci (Executive): Uyumlu, düzenli, verilen talimatları izleyen. Bu stile sahip kişiler kendilerine hazır ya da planlanmış olarak verilen problemleri çözmeyi severler. Yasamacı stildeki kişilere sıkıcı gelen bürokratik işlere yürütmeci stildeki kişiler tahammül edebilirler. Meslek olarak polis memurluğu, öğretmenlik, yöneticilik, tıp doktorluğu vb. seçme eğilimindedirler.

3. Yargılayıcı (Judicial): Yargılayan, değerlendiren, görüş belirten. Bu stile sahip kişiler nesneleri ve görüşleri çözümleyebilecekleri ve değerlendirebilecekleri problemleri tercih ederler. Hem yapıyı hem de içeriği yargılamaktan hoşlanırlar. Dolayısıyla yargılayıcı kişiler yasamacı kişilerin önerilerinin gerçekten uygun olup olmadıklarını değerlendirme işlevini yerine getirirler. Mesleki açıdan eleştiri yazmak, görüş bildirmek, insanları ve programları değerlendirmek, öğrenci kabul görevliliği vb. işleri tercih ederler.

\section{Biçimler (Forms)}

4. Monarşik (Monarchic): Aynı anda tek amaca ve işe odaklanan. Monarşik kişiler olayları "uğraştikları şey" açısından görme eğilimindedirler. Eğer bu stile sahip bir kişi, bir şeyin tercih ettiği konuyla ilgisini görmezse o konudan sıkılabilir. Bu nedenle monarşik kişilerin ilgisini çekmek için teklif edilen şeyin onun odaklandığı konuyla ilişkilendirilmesi yararlı olabilir.

5. Hiyerarşik (Hierarchic): Çok işi, aynı anda, öncelik belirleyerek yapan. Bu stile sahip kişiler, bazı hedeflerin diğerlerinden daha önemli olduğunu bilir ve hedeflerin önem derecelerine göre sıralanmasıyla motive olurlar. Önceliklerini belirlemeye ve kaynaklarını dikkatli dağıtmaya çalışırlar.

6. Oligarşik (Oligarchic): Çok işi, aynı anda, öncelikleri belirleyemeden yapan. Bu stile sahip kişiler genellikle hedeflere eşit derecede önem verirler, kaynakları bölüştürmekte zorlanabilirler, işlerin öncelik sırasını belirleyemedikleri için yönlendirilmeye ihtiyaç duyabilirler.

7. Anarşik (Anarchic): İşlere rastgele yaklaşan, sistemlerden kaçınan. Anarşik stile sahip kişiler, genellikle yalnız kendileri için değil başkaları için de zor olan çok çeşitli gereksinim ve hedeflerle motive olma eğilimindedirler. Sorunlara karşı gelişigüzel bir yaklaşım benimsemeye meyillidirler. Okul ortamında anarşik stildeki öğrenciler uyum sorunları yaşarlar ve okuldan fiziksel ya da psikolojik olarak kopabilirler. Anarşik stilin özellikleri olumsuz gibi görünse de özellikle sistemi sorgulama özelliği ile bu stil yararlı olarak tanımlanmaktadır. Ayrıca genelde insanların düşüncelerle eylemler arasına çizdikleri sınırlar anarşik stildeki insanları kısıtlamadığı için çoğu insandan farklı bir yaratıcılığa sahip olabilirler.

\section{Düzeyler (Levels)}

8. Bütünsel (Global): Soyut düşüncelerle, genel çerçeveyle uğraşan. Tek tek ayrıntllarla ilgilenmek yerine resmin bütününe odaklanan bütünsel kişiler, ağaçları değil ormanı görmeyi tercih ederler. Bu nedenle bazen gerekli küçük ayrıntıları gözden kaçırabilirler.

9. Ayrıntısal (Local): Somut düşüncelerle, ayrıntılarla uğraşan. Bazen önemsiz ve çoğunlukla da somut konularla ilgili ayrıntılara odaklanan Ayrıntısal kişiler, yalnızca ormanı oluşturan ağaçlara tek tek odaklandıkları için ormanın bütününü görmekte zorlanırlar.

\section{Yönelim (Scope)}

10. İçsel (Internal): Bağımsız, kendine yeten, iletişimden kaçınan. İçsel stile sahip kişiler içlerine kapanık, göreve 
odaklı, bazen mesafeli ve sosyal açıdan diğer insanlardan daha duyarsız olma eğilimindedirler. Geleneksel eğitim sistemi biraz dışsal eğilimleri olan içsel öğrencilere avantaj sağlayıcı niteliktedir.

11. Dışsal (External): Başkalarıyla çalışan, sosyal olan, bağımlı olan. Dışsal stildeki insanlar dışa dönük, insana odaklı, cana yakın, sosyal açıdan daha duyarlı ve bireyler arası bilince sahip olma eğilimindedirler. Günümüzdeki bazı eğitim yaklaşımları (iş birliğine dayalı öğrenme gibi) dışsal stildeki öğrencilere avantaj sağlayıcı niteliktedir.

\section{Eğilimler (Leanings)}

12. Liberal (Liberal): Yenilikçi, geleneğe karşı çıkan, hayalci. Liberal stildeki kişiler mevcut kural ve prosedürlerin ötesine geçerek değişimi en üst düzeye çıkarmaktan hoşlanırlar. Hayatlarında bir miktar yabancı unsur bulunması, belirsizlik durumlarından rahatsı olmazlar. Bununla birlikte Yasamacı stilin aksine liberal kişiler için yeni fikirlerin kendilerine ait olması gerekmez.

13. Tutucu (Conservative): Geleneksel, denenmişi tercih eden, gerçekçi. Muhafazakâr kişiler mevcut kural ve prosedürlere sadık kalmayı tercih ederler. Değişimden ve belirsizliklerden hoşlanmazlar, işlerinde ve yaşamlarında tanıdık unsurları tercih ederler. Yürütmeci stildeki kişilerin aksine muhafazakâr kişiler kendi fikirlerini ortaya koymak isteyebilirler ancak bu fikirler mevcut geleneklere dayalı olurlar (Stenberg 1988, 1997 ve 2009; Sternberg \& Grigorenko, 1997).

Eğitim-öğretim işlerinin organize edilmesinde, programların hazırlanmasında, uygulanmasında ve ihtiyaçlara göre yeniden düzenlenmesinde intiyaçların doğru tanımlanması kadar bu işlerde çeşitli görevler alacak olan bireylerin de iyi tanınmasında yarar vardır. Eğitim-öğretim işlerinin doğrudan hedefi olan öğrencilerin öğrenmelerine etki eden unsurların iyi tanınmasının ve bu unsurların birbirleriyle ilişkilerinin iyi analiz edilmesinin, öğretimin etkililiğini doğrudan etkileyeceği düşünülmektedir. Bu unsurlardan biri de bireyin düşünme stilleridir denilebilir. Stil kavramının çeşitli değişkenlerle ilişkisini inceleyen pek çok alanda araştırma yapılmıştı. Düşünme stilleri araştırmaları ağırlıklı olarak Amerika (Dai \& Feldhusen, 1999; Zhang, 2000b), Hong-Kong (Zhang \& Sachs, 1997; Zhang, 1999; Zhang, 2000a; Zhang \& Sternberg, 2000; Zhang \& Sternberg, 2002; Zhang, 2003), Çin (Zhang, 2004; Zhang, 2009) gibi ülkelerde yapılmakla birlikte Kore (Park, Park, \& Choe, 2005), ìspanya (Cano-García \& Hughes, 2000), Filipinler (Valencia, 2007), İran (Alborzi \& Ostovar, 2007; Bibak, 2016) gibi ülkelerde de yapılan çalışmalar bulunmaktadır. Ülkemizde ise çeşitli alanlardan araştırmacıların yaptığı pek çok düşünme stilleri araştırmaları (Akbulut, 2006; Başol \& Türkoğlu, 2009; Buluş, 2005; Buluş, 2006; Dinçer, 2009; Esmer, 2013; Özbek Baştuğ \& Çelik, 2014; Tüzer, 2016) bulunmaktadır. Yerli ve yabancı literatüre bakıldığında çeşitli branşlarda öğretmenlerin, öğretmen adaylarının, okul yöneticilerinin ve öğrencilerin düşünme stillerinin demografik değişkenler (yaş, cinsiyet, mezun olunan okul, çalışılan okulun bulunduğu yerleşim yeri, akademik başarı, medeni hal, mesleki kıdem, seyahat tecrübesi vb.) açısından incelendiği çalışmalar bulunmaktadır. Türkiye'de mesleki müzik eğitimi alan öğrencilerin dönemlere ve bireysel çalgılarına göre düşünme stillerini kullanma düzeylerini belirlemek amacıyla yapılan bir araştırmaya göre mesleki müzik eğitimi alan üniversite öğrencilerinin 1. Tip olarak tanımlanan düşünme stillerini (yasamacı, hiyerarşik ve liberal) yüksek düzeyde kullandıkları, bunun yanı sıra bütünsel ve yürütmeci düşünme stilleri puanlarının da yüksek olduğu belirtilmiştir (Akbulut, 2006). Akbulut'un çalışmasından farklı olarak bu çalışmada öğrencilerin cinsiyet, sınıf düzeyi, mezun olunan okul türü ve AGNO düzeyleri gibi demografik değişkenlere göre düşünme stillerinde bir değişiklik görülüp görülmediğine bakılmışttr.

Ülkemizde bireysel farklılıkların en belirgin olduğu müzik eğitimi alanında, öğrenme süreçlerini yönetmede önemli etki edebilecek olan düşünme stilleri üzerine bir adet çalışma yapıldığı görülmektedir. Bu nedenle bu çalışma mesleki müzik eğitimi alan üniversite öğrencilerinin düşünme stillerinin belirlenmesi ve bu stillerle çeşitli demografik değişkenler arasındaki ilişkinin incelenmesi amacıyla yapılmıştır. Demografik değişkenler cinsiyet, sınıf düzeyi, mezun olunan okul türü, AGNO (Ağırlıklı Genel Not Ortalaması) ve bireysel çalgı olarak belirlenmiştir.

\section{Yöntem}

\section{Çalışma Grubu}

Mesleki müzik eğitimi alan üniversite öğrencilerinin düşünme stillerinin belirlenmesi ve bu stillerle çeşitli demografik değişkenler arasındaki ilişkinin incelenmesi amacıyla yapılan bu çalışma; Atatürk Üniversitesi Güzel Sanatlar Fakültesi'nde 2016-2017 eğitim-öğretim yılında lisans eğitimi almakta olan 94 öğrenci ile yürütülmüştür. Çalışma grubuna ilişkin kişisel bilgiler Tablo 1'de verilmiştir. 
Tablo 1. Çalışma grubuna ait kişisel bilgiler

\begin{tabular}{|c|c|c|c|}
\hline Değişken & Seçenekler & $f$ & $\%$ \\
\hline \multirow{3}{*}{ Cinsiyet } & Kadın & 41 & 43,6 \\
\hline & Erkek & 53 & 56,4 \\
\hline & Toplam & 94 & 100 \\
\hline \multirow{5}{*}{ Sınıf Düzeyi } & 1. sinıf & 21 & 22,3 \\
\hline & 2. sinIf & 23 & 24,5 \\
\hline & 3. sinif & 20 & 21,3 \\
\hline & 4. sinıf & 30 & 31,9 \\
\hline & Toplam & 94 & 100 \\
\hline \multirow{3}{*}{ Mezun Olunan Okul Türü } & GSL & 37 & 39,4 \\
\hline & Diğer & 57 & 60,6 \\
\hline & Toplam & 94 & 100 \\
\hline \multirow{14}{*}{ Bireysel Çalgı } & Bağlama & 24 & 25,5 \\
\hline & Keman & 13 & 13,8 \\
\hline & Gitar & 9 & 9,6 \\
\hline & Çello & 8 & 8,5 \\
\hline & Piyano & 8 & 8,5 \\
\hline & Flüt & 6 & 6,4 \\
\hline & Ud & 6 & 6,4 \\
\hline & Kanun & 5 & 5,3 \\
\hline & Viyola & 5 & 5,3 \\
\hline & Mey & 3 & 3,2 \\
\hline & Tambur & 3 & 3,2 \\
\hline & Şan & 3 & 3,2 \\
\hline & Belirtilmemiş & 1 & 1,1 \\
\hline & Toplam & 94 & 100 \\
\hline
\end{tabular}

\section{Veri Toplama Aracı ve Yöntemi}

Araştırmanın verileri Sternberg ve Wagner (1991) tarafindan geliştirilen ve Fer (2005) tarafindan Türkçe'ye çevrilerek geçerliği ve güvenirliği yapılmış olan "Düşünme Stilleri Envanteri" ile elde edilmiştir. Bu envanter düşünme stillerini ölçme konusunda genel kabul görmüş ve değişik kültürlerde çeşitli yaş gruplarında yeterince denenmiş olması nedeniyle seçilmiştir.

Düşünme Stilleri Envanteri, 5 temel boyut altında yer alan 13 düşünme stilinden, bireyde baskın olanları ortaya çıkarmayı amaçlamaktadır. Envanterin tümünden alınan bir puan yoktur. Çünkü bir temel boyut altında yer alan alt ölçeklerle bireyde baskın olan düşünme stili diğer boyutlardan bağımsız olarak ölçülmektedir. Puanların analizi alt ölçek puanlarının alt ölçekteki madde sayısına bölünmesiyle yapılmaktadır. Bir alt ölçekten alınan puanlar 1 ile 8 arasında değişmekte, elde edilen sürekli puanlar ise kişileri temel boyut altında yer alan düşünme stiline göre gruplandırmak için kullanılmaktadır. Her birey en yüksek puanı aldığı temel düşünme boyutu altındaki alt ölçeğe ait düşünme stiline atanmaktadır. Envanter, tamamı olumlu cümlelerle kurulmuş 104 maddeden oluşmaktadır. Değerlendirme yedili likert tiptedir. Düşünme Stilleri Envanterinin İngilizce ve Türkçe formu arasındaki tutarlılığı incelemek için yapılan Pearson korelasyon testi sonucunda 4. ve 73. dışındaki tüm maddelerde 0.40 ile 0.99 arasında değişen ve 0.01 düzeyinde pozitif ve anlamlı değerlere ulaşılmıştır. Envanterin yapı geçerliğini saptamak için yapılan faktör analizi; 5 faktörlü, 13 alt ölçekli, 70 maddeli bir yapı ortaya koymuştur. Envanterin bütününün iç tutarlık güvenirliği için alpha katsayısı 0.89 olarak bulunmuştur. Bulgular, alt ölçek maddelerinin iç tutarlık güvenirliğinin 0.37-0.88 arasında değişen madde-toplam korelasyonu olduğunu göstermiştir. Alt ölçeklerin dış tutarlık güvenirliği için yapılan test-tekrar test tekniği bulguları ise 0.63-0.78 arasında korelasyon değeri almıştır (Fer, 2005).

Araştırma kapsamında düşünme stilleri ile ilişkisi incelenen demografik veriler ise, araştırmacı tarafindan oluşturulan kişisel bilgi formu kullanılarak toplanmıştır. Kişisel bilgi formu, araştırma kapsamında ele alınan demografik değişkenleri (cinsiyet, sınıf düzeyi, mezun olunan okul türü, AGNO ve bireysel çalgı) belirlemeye yönelik çoktan seçmeli ve açık uçlu sorulardan oluşmaktadır. 


\section{Verilerin Analizi}

Düşünme stilleri envanteri ve kişisel bilgi formu ile elde edilen veriler tek yönlü varyans analizi (ANOVA), Tukey HSD testi ve betimleyici istatistiki teknikler kullanılarak analiz edilmiş ve analiz sonucunda elde edilen bulgular tablolar halinde verilmiştir. Varyans analizi, $\mathrm{k}$ bağımsız ya da $\mathrm{k}$ bağımlı gruptan elde edilen verilerin grup ortalamalarının ya da işlem ortalamalarının farkııığını test etmek için kullanılır. Tek yönlü varyans analizi, normal dağıım gösteren $\mathrm{k}$ toplumdan alınan $k$ bağımsız grup nicel verilerin analizinde kullanılır. Tek yönlü varyans analizi sonucuna göre $p<0,05$ ise grup ortalamaları birbirinden önemli düzeyde farklıdır. Bu durumda hangi grupların farklı olduğunu belirlemek için çoklu karşılaştırma testleri uygulanmaktadır. Bu testlerden biri olan Tukey HSD testi tüm olası farkları gerçekten önemli fark değerine göre test eder. Grup ortalamalarını eşanlı olarak karşılaştırmayı amaçlayan Tukey HSD testi gruplarda birim sayılarının eşit olduğunu varsayar. Birim sayılarının eşit olmadığı durumlarda grup birim sayılarının harmonik ortalamasını kullanır (Özdamar, 2009). ANOVA yapılabilmesi için grupların varyanslarının homojen olması şartı aranır. Homojenlik testi Levene istatistiği ile yapılır. Homojenlik testi sonuçlarına göre grup varyanslarının homojen olmadığı durumlarda ANOVA yerine alternatifi olarak kabul edilen Welch ve Brown-Forsythe testleri uygulanır. İki test arasında Welch testi daha güçlü olup daha sık tercih edilir (Durmuş, Yurtkoru \& Çinko, 2016, s. 133).

\section{Bulgular}

Bu bölümde, düşünme stilleri envanteri ve kişisel bilgi formundan elde edilen verilere ilgili istatistik analizler yapılarak ulaşılan bulgular yer almaktadır. Düşünme stilleri envanteri kullanılarak toplanan veriler 94 kişiden oluşan bir çalışma grubundan elde edilmiştir. Ancak verilerin toplanması sırasında katılımcıların 104 soruluk veri toplama aracındaki bazı soruları boş bırakmalarından dolayı istatistik testler her alt boyut için tüm sorulara cevap veren katılımcı sayısına göre yapılmıştır. Bu nedenle aşağıdaki tablolarda yer alan katılımcı sayıları ( $\mathrm{N}$ değerleri) değişiklik göstermektedir. Illk olarak çalışma grubunun genel düşünme stili profilini belirlemek amacıyla Düşünme Stili Envanteri puan ortalamalarının genel dağılımına betimsel olarak bakılmıştır. Puan ortalamaları Tablo 2'de verilmiştir.

Tablo 2. Çalışma grubunun düşünme stilleri envanteri puan ortalamalarının genel dağılımı

\begin{tabular}{lccccc}
\hline Düşünme Stilleri & N & En Az & En Çok & Ortalama & Std. Sapma \\
\hline Yasamacı & 86 & 3,00 & 7,00 & 5,80 &, 804 \\
Yürütmeci & 87 & 3,75 & 7,00 & 5,34 &, 787 \\
Yargılayıcı & 88 & 2,00 & 7,00 & 5,09 & 1,064 \\
Monarşik & 90 & 2,25 & 7,00 & 4,80 & 1,012 \\
Hiyerarşik & 89 & 1,88 & 7,00 & 5,62 & 1,083 \\
Oligarşik & 85 & 1,88 & 7,00 & 4,54 & 1,035 \\
Anarşik & 86 & 2,00 & 7,00 & 4,87 & 1,033 \\
Bütünsel & 91 & 2,63 & 7,00 & 4,80 & 1,028 \\
Ayrıntisal & 90 & 2,75 & 7,00 & 4,84 & 1,061 \\
İçsel & 86 & 1,00 & 7,00 & 4,89 & 1,278 \\
Dişadönük & 88 & 1,75 & 7,00 & 5,02 & 1,295 \\
Liberal & 84 & 2,63 & 7,00 & 5,52 &, 938 \\
Tutucu & 88 & 2,00 & 7,00 & 4,50 & 1,355 \\
\hline
\end{tabular}

Tablo 2'deki bulgular çalışma grubunun Düşünme Stilleri Envanterinden elde edilen puan ortalamalarının tüm alt boyutlarda 4,50'nin üzerinde olduğunu göstermektedir. En yüksek ortalama 5,80 puan ile Yasamacı düşünme stili alt boyutunda görülürken, en düşük ortalama ise 4,50 puanla Tutucu düşünme stili alt boyutunda görülmüştür. Tablo 2'de yer alan bulgulara göre çalışma grubunun genel olarak Yasamacı, Yürütmeci, Yargılayıcı, Hiyerarşik, Dışsal ve Liberal düşünme stillerine daha yüksek düzeyde sahip oldukları söylenebilir.

Çalışma grubunun demografik özellikleri ile düşünme stilleri arasındaki ilişkiyi incelemek amacıyla ANOVA testi yapılmış, test sonuçları tablolar halinde ve tabloların yorumları da altlarında verilmiştir. ANOVA öncesinde düşünme stillerinin cinsiyete göre grup varyanslarının homojenliğini sınamak için yapılan Levene testi bulguları, düşünme stillerinin cinsiyet gruplarının varyansları arasında anlamlı fark olmadığıı $(p>0,05)$, grup varyanslarının homojen olduğunu göstermiştir. 
Tablo 3. Düşünme stillerinin cinsiyet gruplarına göre ANOVA testi sonuçları

\begin{tabular}{|c|c|c|c|c|c|c|}
\hline \multicolumn{7}{|c|}{ ANOVA } \\
\hline \multicolumn{2}{|c|}{ Düşünme Stilleri } & Kareler Toplamı & Sd & Kareler Ortalaması & $\mathrm{F}$ & $\mathrm{p}$ \\
\hline & Gruplar Arası & 2,698 & 1 & 2,698 & 4,334 & $040^{*}$ \\
\hline \multirow[t]{3}{*}{ Yasamacı } & Gruplar İçi & 52,299 & 84 & ,623 & & \\
\hline & Toplam & 54,997 & 85 & & & \\
\hline & Gruplar Arası & , 014 & 1 & ,014 & ,022 & ,881 \\
\hline \multirow[t]{3}{*}{ Yürütmeci } & Gruplar İçi & 53,274 & 85 & ,627 & & \\
\hline & Toplam & 53,288 & 86 & & & \\
\hline & Gruplar Arası & 1,378 & 1 & 1,378 & 1,211 & ,274 \\
\hline \multirow[t]{3}{*}{ Yargılayıcı } & Gruplar İçi & 97,902 & 86 & 1,138 & & \\
\hline & Toplam & 99,280 & 87 & & & \\
\hline & Gruplar Arası & ,560 & 1 & ,560 & ,544 & ,463 \\
\hline \multirow[t]{3}{*}{ Monarşik } & Gruplar İçi & 90,502 & 88 & 1,028 & & \\
\hline & Toplam & 91,062 & 89 & & & \\
\hline & Gruplar Arası & ,628 & 1 & ,628 & ,533 & 467 \\
\hline \multirow[t]{3}{*}{ Hiyerarşik } & Gruplar İçi & 102,508 & 87 & 1,178 & & \\
\hline & Toplam & 103,136 & 88 & & & \\
\hline & Gruplar Arası & ,972 & 1 & ,972 & ,907 & 344 \\
\hline \multirow[t]{3}{*}{ Oligarşik } & Gruplar İçi & 88,956 & 83 & 1,072 & & \\
\hline & Toplam & 89,928 & 84 & & & \\
\hline & Gruplar Arası & 5,606 & 1 & 5,606 & 5,539 &, $021^{*}$ \\
\hline \multirow[t]{3}{*}{ Anarşik } & Gruplar İçi & 85,016 & 84 & 1,012 & & \\
\hline & Toplam & 90,622 & 85 & & & \\
\hline & Gruplar Arası & ,023 & 1 & ,023 & ,021 & ,885 \\
\hline \multirow[t]{3}{*}{ Bütünsel } & Gruplar İçi & 95,073 & 89 & 1,068 & & \\
\hline & Toplam & 95,096 & 90 & & & \\
\hline & Gruplar Arası & 2,254 & 1 & 2,254 & 2,027 & 158 \\
\hline \multirow[t]{3}{*}{ Ayrıntisal } & Gruplar İçi & 97,849 & 88 & 1,112 & & \\
\hline & Toplam & 100,103 & 89 & & & \\
\hline & Gruplar Arası & ,059 & 1 & ,059 & ,036 & ,850 \\
\hline \multirow[t]{3}{*}{ İçsel } & Gruplar İçi & 138,785 & 84 & 1,652 & & \\
\hline & Toplam & 138,845 & 85 & & & \\
\hline & Gruplar Arası & 3,407 & 1 & 3,407 & 2,055 & 155 \\
\hline \multirow[t]{3}{*}{ Dışsal } & Gruplar İçi & 142,547 & 86 & 1,658 & & \\
\hline & Toplam & 145,954 & 87 & & & \\
\hline & Gruplar Arası & 2,287 & 1 & 2,287 & 2,654 & 107 \\
\hline \multirow[t]{3}{*}{ Liberal } & Gruplar İçi & 70,665 & 82 & ,862 & & \\
\hline & Toplam & 72,952 & 83 & & & \\
\hline & Gruplar Arası & 2,293 & 1 & 2,293 & 1,252 & ,266 \\
\hline \multirow[t]{2}{*}{ Tutucu } & Gruplar İçi & 157,533 & 86 & 1,832 & & \\
\hline & Toplam & 159,827 & 87 & & & \\
\hline
\end{tabular}

Tablo 3'e bakıldığında çalışma grubunun genel olarak düşünme stillerinde cinsiyet değişkenine göre anlamlı farklılıklar olmadığı görülmektedir. Yalnızca Yasamacı $(F(1,85)=4,334, p<.050)$ ve Anarşik $(F=5,539, p<.050)$ düşünme stillerinde cinsiyete göre anlamlı farklılıklar görülmektedir.

Tablo 4. Düşünme stillerinin cinsiyet değişkenine göre betimsel değerleri

\begin{tabular}{llccr}
\hline \multicolumn{4}{c}{ Betimsel Değerler } \\
\hline Düşünme Stilleri & Cinsiyet & $\mathrm{N}$ & Ortalama & Std. Sapma \\
\hline \multirow{3}{*}{ Yasamacı } & Kadın & 37 & 5,59 &, 808 \\
& Erkek & 49 & 5,95 &, 774 \\
& Toplam & 86 & 5,80 &, 804 \\
\hline
\end{tabular}




\begin{tabular}{|c|c|c|c|c|}
\hline \multicolumn{5}{|c|}{ Betimsel Değerler } \\
\hline Düşünme Stilleri & Cinsiyet & $\mathrm{N}$ & Ortalama & Std. Sapma \\
\hline \multirow{3}{*}{ Yürütmeci } & Kadın & 38 & 5,33 & 794 \\
\hline & Erkek & 49 & 5,35 & 790 \\
\hline & Toplam & 87 & 5,34 & ,787 \\
\hline \multirow{3}{*}{ Yargılayıcı } & Kadın & 37 & 4,94 & 1,175 \\
\hline & Erkek & 51 & 5,20 & 982 \\
\hline & Toplam & 88 & 5,09 & 1,068 \\
\hline \multirow{3}{*}{ Monarşik } & Kadın & 38 & 4,71 & 926 \\
\hline & Erkek & 52 & 4,87 & 1,074 \\
\hline & Toplam & 90 & 4,80 & 1,012 \\
\hline \multirow{3}{*}{ Hiyerarşik } & Kadın & 40 & 5,53 & 1,232 \\
\hline & Erkek & 49 & 5,69 & ,950 \\
\hline & Toplam & 89 & 5,62 & 1,083 \\
\hline \multirow{3}{*}{ Oligarşik } & Kadın & 37 & 4,42 & 1,064 \\
\hline & Erkek & 48 & 4,64 & 1,013 \\
\hline & Toplam & 85 & 4,54 & 1,035 \\
\hline \multirow{3}{*}{ Anarşik } & Kadın & 38 & 4,58 & 1,079 \\
\hline & Erkek & 48 & 5,10 & 945 \\
\hline & Toplam & 86 & 4,87 & 1,033 \\
\hline \multirow{3}{*}{ Bütünsel } & Kadın & 40 & 4,78 & 1,034 \\
\hline & Erkek & 51 & 4,82 & 1,033 \\
\hline & Toplam & 91 & 4,80 & 1,028 \\
\hline \multirow{3}{*}{ Ayrıntisal } & Kadın & 39 & 4,66 & 1,083 \\
\hline & Erkek & 51 & 4,98 & 1,032 \\
\hline & Toplam & 90 & 4,84 & 1,061 \\
\hline \multirow{3}{*}{ İçsel } & Kadın & 38 & 4,86 & 1,160 \\
\hline & Erkek & 48 & 4,91 & 1,376 \\
\hline & Toplam & 86 & 4,89 & 1,278 \\
\hline \multirow{3}{*}{ Dışsal } & Kadın & 38 & 4,79 & 1,388 \\
\hline & Erkek & 50 & 5,19 & 1,206 \\
\hline & Toplam & 88 & 5,02 & 1,295 \\
\hline \multirow{3}{*}{ Liberal } & Kadın & 37 & 5,34 & 1,039 \\
\hline & Erkek & 47 & 5,67 & ,832 \\
\hline & Toplam & 84 & 5,52 & ,938 \\
\hline \multirow{3}{*}{ Tutucu } & Kadın & 38 & 4,32 & 1,378 \\
\hline & Erkek & 50 & 4,65 & 1,334 \\
\hline & Toplam & 88 & 4,50 & 1,355 \\
\hline
\end{tabular}

Tablo 4'teki bulgular düşünme stilleri envanterinden elde edilen alt ölçek ortalamalarının, cinsiyete göre bazı farklılıklar göstermekle birlikte genelde orta düzeyin üzerinde olduğunu göstermektedir. Kadın grubunda en düşük ortalama 4,32 puanla Liberal düşünme stili alt boyutunda görülürken erkek grubunda en düşük ortalama 4,64 puanla Oligarşik düşünme stili alt boyutunda görülmüştür. Kadınlarda en yüksek ortalama 5,53 puanla Monarşik düşünme stili alt boyutunda, erkeklerde ise en yüksek ortalama 5,95 puanla Yasamacı düşünme stili alt boyutunda görülmektedir. Çalışma grubunun düşünme stilleri ile cinsiyet değişkeni arasındaki ilişkiyi gösteren bulgular kadınların genel olarak Monarşik düşünme stiline erkeklerin ise Yasamacı düşünme stiline sahip olduklarını göstermiştir.

Düşünme stillerinin sınıf düzeyi gruplarının varyanslarının homojenliğini sınamak için yapılan Levene testi bulguları, düşünme stillerinin sınıf düzeyi gruplarının varyansları arasında anlamlı fark olmadığını ( $>>0,05)$, grup varyanslarının homojen olduğunu göstermiştir. 
Tablo 5. Düşünme stillerinin sınıf düzeyine göre ANOVA testi sonuçları

\begin{tabular}{|c|c|c|c|c|c|c|}
\hline \multicolumn{7}{|c|}{ ANOVA } \\
\hline \multicolumn{2}{|c|}{ Düşünme Stilleri } & Kareler Toplamı & $\mathrm{Sd}$ & Kareler Ortalaması & $\mathrm{F}$ & $\mathrm{p}$ \\
\hline & Gruplar Arası & 6,203 & 3 & 2,068 & 3,474 & ,020* \\
\hline \multirow[t]{3}{*}{ Yasamacı } & Gruplar İçi & 48,795 & 82 & ,595 & & \\
\hline & Toplam & 54,997 & 85 & & & \\
\hline & Gruplar Arası & 2,207 & 3 & ,736 & 1,196 & 317 \\
\hline \multirow[t]{3}{*}{ Yürütmeci } & Gruplar İçi & 51,081 & 83 & 615 & & \\
\hline & Toplam & 53,288 & 86 & & & \\
\hline & Gruplar Arası & 2,644 & 3 & ,881 & ,766 & ,516 \\
\hline \multirow[t]{3}{*}{ Yargılayıcı } & Gruplar İçi & 96,636 & 84 & 1,150 & & \\
\hline & Toplam & 99,280 & 87 & & & \\
\hline & Gruplar Arası & 893 & 3 & 298 & ,284 & ,837 \\
\hline \multirow[t]{3}{*}{ Monarşik } & Gruplar İçi & 90,169 & 86 & 1,048 & & \\
\hline & Toplam & 91,062 & 89 & & & \\
\hline & Gruplar Arası & 8,160 & 3 & 2,720 & 2,434 & 070 \\
\hline \multirow[t]{3}{*}{ Hiyerarşik } & Gruplar İçi & 94,976 & 85 & 1,117 & & \\
\hline & Toplam & 103,136 & 88 & & & \\
\hline & Gruplar Arası & 2,712 & 3 & 904 & ,839 & ,476 \\
\hline \multirow[t]{3}{*}{ Oligarşik } & Gruplar İçi & 87,217 & 81 & 1,077 & & \\
\hline & Toplam & 89,928 & 84 & & & \\
\hline & Gruplar Arası & 3,483 & 3 & 1,161 & 1,093 & 357 \\
\hline \multirow[t]{3}{*}{ Anarşik } & Gruplar İçi & 87,139 & 82 & 1,063 & & \\
\hline & Toplam & 90,622 & 85 & & & \\
\hline & Gruplar Arası & 9,921 & 3 & 3,307 & 3,378 &, $022^{*}$ \\
\hline \multirow[t]{3}{*}{ Bütünsel } & Gruplar İçi & 85,175 & 87 & 979 & & \\
\hline & Toplam & 95,096 & 90 & & & \\
\hline & Gruplar Arası & 10,412 & 3 & 3,471 & 3,328 &, $023^{*}$ \\
\hline \multirow[t]{3}{*}{ Ayrıntisal } & Gruplar İçi & 89,692 & 86 & 1,043 & & \\
\hline & Toplam & 100,103 & 89 & & & \\
\hline & Gruplar Arası & 9,839 & 3 & 3,280 & 2,085 & 109 \\
\hline \multirow[t]{3}{*}{ İçsel } & Gruplar İçi & 129,006 & 82 & 1,573 & & \\
\hline & Toplam & 138,845 & 85 & & & \\
\hline & Gruplar Arası & 11,300 & 3 & 3,767 & 2,350 & ,078 \\
\hline \multirow[t]{3}{*}{ Dışsal } & Gruplar İçi & 134,654 & 84 & 1,603 & & \\
\hline & Toplam & 145,954 & 87 & & & \\
\hline & Gruplar Arası & 1,777 & 3 & ,592 & ,666 & ,575 \\
\hline \multirow[t]{3}{*}{ Liberal } & Gruplar İçi & 71,175 & 80 & ,890 & & \\
\hline & Toplam & 72,952 & 83 & & & \\
\hline & Gruplar Arası & 6,570 & 3 & 2,190 & 1,200 & ,315 \\
\hline \multirow[t]{2}{*}{ Tutucu } & Gruplar İçi & 153,256 & 84 & 1,824 & & \\
\hline & Toplam & 159,827 & 87 & & & \\
\hline
\end{tabular}

Tablo 5'e bakıldığında çalışma grubunun genel olarak düşünme stillerinde sınıf düzeyine göre anlamlı farklılıklar olmadığı görülmektedir. Ancak Yasamacı $(F=3,474, p<.050)$, Bütünsel $(F=3,378, p<.050)$ ve Ayrıntisal $(F=3,328, p<.050)$ düşünme stilleri sınıf düzeyine göre anlamlı farklılıklar göstermektedir. Bu durumda hangi sınıf düzeylerine göre farklıık olduğunu belirlemek amacıyla Tukey HSD çoklu karşılaştırma testi yapılmış ve sonuçlar Tablo 6'da verilmiştir. 
Tablo 6. Düşünme stillerinin sınıf düzeyine göre çoklu karşılaştırma testi sonuçları

\begin{tabular}{|c|c|c|c|c|c|c|}
\hline \multicolumn{7}{|c|}{ Çoklu Karşılaştirma } \\
\hline \multicolumn{2}{|c|}{ Düşünme Stilleri } & (I) Sınıf Düzeyi & $\begin{array}{l}\text { (J) Sınıf } \\
\text { Düzeyi }\end{array}$ & Ortalama Fark (I-J) & Std. Hata & $p$ \\
\hline \multirow{12}{*}{ Yasamacı } & \multirow{12}{*}{ Tukey HSD } & \multirow{3}{*}{ 1.Sinıf } & 2.Sınıf &,$- 64223^{* *}$ & ,24424 &, $049^{*}$ \\
\hline & & & 3.Sinıf &,- 24342 & 25373 & ,773 \\
\hline & & & 4.Sınıf &,$- 63181^{* *}$ & ,22928 &, $036^{*}$ \\
\hline & & \multirow{3}{*}{ 2.Sinıf } & 1.Sınıf &, $64223^{* *}$ & 24424 &, $049^{*}$ \\
\hline & & & 3.Sınıf & ,39881 & 24778 & 379 \\
\hline & & & 4.Sinıf & ,01042 & ,22268 & 1,000 \\
\hline & & \multirow{3}{*}{ 3.Sınıf } & 1.Sınıf & 24342 & 25373 & 773 \\
\hline & & & 2.Sınıf &,- 39881 & 24778 & 379 \\
\hline & & & 4.Sinıf &,- 38839 & 23305 & 348 \\
\hline & & \multirow{3}{*}{ 4.Sinıf } & 1.Sınıf & $63181^{* *}$ & 22928 &, $036^{*}$ \\
\hline & & & 2.Sinıf &,- 01042 & ,22268 & 1,000 \\
\hline & & & 3.Sınıf & ,38839 & ,23305 & ,348 \\
\hline \multirow{12}{*}{ Bütünsel } & \multirow{12}{*}{ Tukey HSD } & \multirow{3}{*}{ 1.Sınıf } & 2.Sinıf & ,40217 & ,30252 & ,547 \\
\hline & & & 3.Sınıf & ,40132 & 31698 & ,587 \\
\hline & & & 4.Sinıf &,- 35345 & ,28759 & ,610 \\
\hline & & \multirow{3}{*}{ 2.Sinıf } & 1.Sınıf &,- 40217 & ,30252 & ,547 \\
\hline & & & 3.Sinıf &,- 00086 & 30675 & 1,000 \\
\hline & & & 4.Sinıf &,$- 75562^{* *}$ & 27627 &, $037^{*}$ \\
\hline & & \multirow{3}{*}{ 3.Sinıf } & 1.Sinıf &,- 40132 & 31698 & ,587 \\
\hline & & & 2.Sinıf & ,00086 & ,30675 & 1,000 \\
\hline & & & 4.Sinıf &,- 75476 & 29204 & ,055 \\
\hline & & \multirow{3}{*}{ 4.Sinıf } & 1.Sınıf & ,35345 & 28759 & ,610 \\
\hline & & & 2.Sinif &, $75562^{* *}$ & ,27627 &, $037^{*}$ \\
\hline & & & 3.Sinıf & ,75476 & 29204 & ,055 \\
\hline \multirow{12}{*}{ Ayrıntisal } & \multirow{12}{*}{ Tukey HSD } & \multirow{3}{*}{ 1.Sinıf } & 2.Sinıf & 15070 & 31156 & ,963 \\
\hline & & & 3.Sinıf & 65298 & 31908 & 179 \\
\hline & & & 4.Sinıf &,- 28638 & 29714 & ,770 \\
\hline & & \multirow{3}{*}{ 2.Sinıf } & 1.Sınıf &,- 15070 & ,31156 & ,963 \\
\hline & & & 3.Sinıf & ,50227 & ,31552 & , 389 \\
\hline & & & 4.Sinıf &,- 43708 & 29331 & ,448 \\
\hline & & \multirow{3}{*}{ 3.Sinıf } & 1.Sinıf &,- 65298 & 31908 & 179 \\
\hline & & & 2.Sınıf &,- 50227 & ,31552 & ,389 \\
\hline & & & 4.Sinıf &,$- 93935^{* *}$ & 30129 &, $013^{*}$ \\
\hline & & \multirow{3}{*}{ 4.Sinıf } & 1.Sınıf & 28638 & 29714 & ,770 \\
\hline & & & 2.Sınıf & 43708 & 29331 & ,448 \\
\hline & & & 3.Sinıf &, $93935^{* *}$ & 30129 &, $013^{*}$ \\
\hline
\end{tabular}

$* p<0.05$

** Ortalama fark 0.05 düzeyinde anlamlıdır.

Hangi gruplar arasında fark olduğunu görebilmek amacıyla yapılan Tukey HSD testi sonuçlarına göre Yasamacı düşünme stilinde 1. sınıf ile 2. ve 4. sınıf grupları arasında; Bütünsel düşünme stilinde 2. sınıf ile 4. sınıf grupları arasında; Ayrıntısal düşünme stilinde ise 3 . sınıf ile 4. sınıf grupları arasında farklılık olduğu görülmektedir. Hangi sınıf düzeyinde hangi düşünme stilinin daha yüksek olduğunu belirlemek için yapılan betimsel istatistik testinden elde edilen sınıf düzeylerinin puan ortalamalarının dağılımlarını gösteren değerler Tablo 7'de yer almaktadır. 
Tablo 7. Düşünme stillerinin sınıf düzeyine göre betimsel dağılımlar

\begin{tabular}{lllcc}
\hline \multicolumn{4}{c}{ Betimsel Değerler } & \\
\hline Düşünme Stilleri & Sınıf Düzeyi & $\mathrm{N}$ & Ortalama & Std. Sapma \\
\hline \multirow{4}{*}{ Yasamacı } & 1. sınıf & 19 & 5,38 &, 658 \\
& 2. sınıf & 21 & 6,02 &, 647 \\
& 3. sınıf & 18 & 5,63 &, 688 \\
& 4. sınıf & 28 & 6,01 &, 804 \\
\hline Toplam & 86 & 5,80 & 1,034 \\
Bütünsel & 1. sınıf & 20 & 4,88 &, 899 \\
& 2. sınıf & 23 & 4,47 &, 942 \\
& 3. sınıf & 19 & 4,47 & 1,054 \\
& 4. sınıf & 29 & 5,23 & 1,028 \\
\hline \multirow{5}{*}{ Ayrıntisal } & Toplam & 91 & 4,80 & 1,149 \\
& 1. sınıf & 21 & 4,94 & 1,035 \\
& 2. sınıf & 22 & 4,79 &, 919 \\
& 3. sınıf & 20 & 4,29 &, 976 \\
& 4. sınıf & 27 & 5,23 & 1,061 \\
\hline
\end{tabular}

Tablo 7’ye bakıldığında 2. sınıf öğrencilerinin Yasamacı düşünme stilinde, 4. sınıf öğrencilerinin ise Yasamacı, Bütünsel ve Ayrıntısal düşünme stillerine daha yüksek düzeyde sahip oldukları görülmektedir. Çalışma grubunun düşünme stilleri ile sınıf düzeyi arasındaki ilişkiyi gösteren bulgular mesleki müzik eğitimi almakta olan öğrencilerin eğitimlerinin sonuna yaklaşttkları 4. sınıf düzeyinde daha Yasamacı, Bütünsel ve Ayrıntısal düşünme stiline sahip oldukları şeklinde yorumlanabilir. Bir başka deyişle 4. Sınıf öğrencilerinin Yasamacı düşünme stiliyle birlikte Bütünsel ve Ayrıntısal düşünme stillerinden oluşan bir stil profiline sahip olduklarını söylemek mümkündür.

Çalışma grubunun mezun olunan okul türü değişkenine göre grup varyanslarının homojenliğini belirlemek için yapılan Levene testi bulgularından Yasamacı ve Liberal düşünme stillerinin mezun olunan okul türü grup varyanslarının homojen olmadığı $(p<0,05)$; diğer düşünme stillerinin grup varyanslarının homojen $(p>0,05)$ olduğu görülmüştür.

Tablo 8. Düşünme stillerinin mezun olunan okul türü gruplarına göre ANOVA testi sonuçları

\begin{tabular}{|c|c|c|c|c|c|c|}
\hline \multicolumn{7}{|c|}{ ANOVA } \\
\hline \multicolumn{2}{|c|}{ Düşünme Stilleri } & Kareler Toplamı & $\mathrm{Sd}$ & Kareler Ortalaması & $\mathrm{F}$ & $p$ \\
\hline \multirow{3}{*}{ Yürütmeci } & Gruplar Arası & 2,834 & 1 & 2,834 & 4,775 & ,032* \\
\hline & Gruplar İçi & 50,454 & 85 & ,594 & & \\
\hline & Toplam & 53,288 & 86 & & & \\
\hline \multirow{3}{*}{ Yargılayıcı } & Gruplar Arası & 6,419 & 1 & 6,419 & 5,945 & , $017^{*}$ \\
\hline & Gruplar İçi & 92,861 & 86 & 1,080 & & \\
\hline & Toplam & 99,280 & 87 & & & \\
\hline \multirow{3}{*}{ Monarşik } & Gruplar Arası & ,017 & 1 & ,017 & ,016 & 899 \\
\hline & Gruplar İçi & 91,045 & 88 & 1,035 & & \\
\hline & Toplam & 91,062 & 89 & & & \\
\hline \multirow{3}{*}{ Hiyerarşik } & Gruplar Arası & 8,498 & 1 & 8,498 & 7,812 & ,006* \\
\hline & Gruplar İçi & 94,639 & 87 & 1,088 & & \\
\hline & Toplam & 103,136 & 88 & & & \\
\hline \multirow{3}{*}{ Oligarşik } & Gruplar Arası & 1,324 & 1 & 1,324 & 1,240 & ,269 \\
\hline & Gruplar İçi & 88,605 & 83 & 1,068 & & \\
\hline & Toplam & 89,928 & 84 & & & \\
\hline \multirow{3}{*}{ Anarşik } & Gruplar Arası & ,665 & 1 & ,665 & ,621 & ,433 \\
\hline & Gruplar İçi & 89,957 & 84 & 1,071 & & \\
\hline & Toplam & 90,622 & 85 & & & \\
\hline \multirow{3}{*}{ Bütünsel } & Gruplar Arası & ,000 & 1 & ,000 & ,000 & ,989 \\
\hline & Gruplar İçi & 95,096 & 89 & 1,068 & & \\
\hline & Toplam & 95,096 & 90 & & & \\
\hline
\end{tabular}




\begin{tabular}{|c|c|c|c|c|c|c|}
\hline \multicolumn{7}{|c|}{ ANOVA } \\
\hline \multicolumn{2}{|c|}{ Düşünme Stilleri } & Kareler Toplamı & Sd & Kareler Ortalaması & $\mathrm{F}$ & $p$ \\
\hline \multirow{3}{*}{ Ayrıntisal } & Gruplar Arası & 2,535 & 1 & 2,535 & 2,287 & 134 \\
\hline & Gruplar İçi & 97,568 & 88 & 1,109 & & \\
\hline & Toplam & 100,103 & 89 & & & \\
\hline \multirow{3}{*}{ İçsel } & Gruplar Arası & 234 & 1 & ,234 & 142 & ,707 \\
\hline & Gruplar İçi & 138,610 & 84 & 1,650 & & \\
\hline & Toplam & 138,845 & 85 & & & \\
\hline \multirow{3}{*}{ Dışsal } & Gruplar Arası & 1,715 & 1 & 1,715 & 1,022 & ,315 \\
\hline & Gruplar İçi & 144,240 & 86 & 1,677 & & \\
\hline & Toplam & 145,954 & 87 & & & \\
\hline \multirow{3}{*}{ Tutucu } & Gruplar Arası & ,993 & 1 & 993 & ,538 & ,465 \\
\hline & Gruplar İçi & 158,833 & 86 & 1,847 & & \\
\hline & Toplam & 159,827 & 87 & & & \\
\hline
\end{tabular}

$* p<0.05$

Tablo 8'e bakıldığında çalışma grubunun mezun olunan okul türü değişkenine göre Yasamacı $(F=10,960, p<.050)$, Yürütmeci $(F=4,775, p<.050)$, Yargılayıcı $(F=5,945, p<.050)$ ve Hiyerarşik $(F=7,812, p<.050)$ düşünme stillerinde anlamlı farklılıklara sahip olduğu görülmektedir. Yasamacı ve Liberal düşünme stillerinin mezun olunan okul türüne göre grup varyansları homojen olmadığı için ANOVA yerine Welch testi uygulanmıştır. Yasamacı ve Liberal düşünme stillerinin mezun olunan okul türüne göre Welch testi sonuçları (Yasamacı $p=0,004<0,005$; Liberal $p=0,005$ ) iki düşünme stili için de gruplar arasında anlamlı fark olduğunu göstermektedir. Hangi okul türünde hangi düşünme stilinin daha yüksek olduğunu belirlemek için yapılan betimsel istatistik testinden elde edilen değerlerin dağılımları Tablo 9'da yer gösterilmiştir.

Tablo 9. Düşünme stillerinin mezun olunan okul türüne göre betimsel dağılımlar

\begin{tabular}{|c|c|c|c|c|}
\hline \multicolumn{5}{|c|}{ Betimsel Değerler } \\
\hline Düşünme Stilleri & Mezun Olunan Okul Türü & $\mathrm{N}$ & Ortalama & Std. Sapma \\
\hline \multirow{3}{*}{ Yasamacı } & Güzel Sanatlar Lisesi & 33 & 5,45 & ,938 \\
\hline & Diğer Liseler & 53 & 6,01 & ,628 \\
\hline & Toplam & 86 & 5,80 & ,804 \\
\hline \multirow{3}{*}{ Yürütmeci } & Güzel Sanatlar Lisesi & 31 & 5,10 & 654 \\
\hline & Diğer Liseler & 56 & 5,48 & ,827 \\
\hline & Toplam & 87 & 5,34 & ,787 \\
\hline \multirow{3}{*}{ Yargılayıcı } & Güzel Sanatlar Lisesi & 35 & 4,76 & 1,057 \\
\hline & Diğer Liseler & 53 & 5,31 & 1,027 \\
\hline & Toplam & 88 & 5,09 & 1,068 \\
\hline \multirow{3}{*}{ Hiyerarşik } & Güzel Sanatlar Lisesi & 36 & 5,24 & 1,130 \\
\hline & Diğer Liseler & 53 & 5,87 & ,980 \\
\hline & Toplam & 89 & 5,62 & 1,083 \\
\hline \multirow{3}{*}{ Liberal } & Güzel Sanatlar Lisesi & 34 & 5,30 & 667 \\
\hline & Diğer Liseler & 50 & 5,68 & 1,064 \\
\hline & Toplam & 84 & 5,52 & ,938 \\
\hline
\end{tabular}

Tablo 9'daki bulgular gösteriyor ki, Güzel Sanatlar Liseleri dışında kalan diğer liselerden mezun olan öğrencilerin Yasamacı, Yürütmeci, Yargılayıcı, Hiyerarşik ve Liberal düşünme stilleri puan ortalamaları Güzel Sanatlar Liselerinden mezun olan öğrencilere göre daha yüksektir. En yüksek ortalama 6,01 puanla Yasamacı düşünme stilinde görülmektedir. Bu durum Güzel Sanatlar Liselerinden mezun olmayan öğrencilerin Yasamacı düşünme stiline yüksek düzeyde sahip olduğunu göstermektedir.

Çalışma grubunun AGNO düzeyi değişkenine göre grup varyanslarının homojenliği testi bulguları, Yasamacı düşünme stilinin AGNO düzeyi grup varyanslarının homojen olmadığını $(p<0,05)$; diğer düşünme stillerinin grup varyanslarının homojen $(p>0,05)$ olduğunu göstermiştir. 
Tablo 10. Düşünme stillerinin AGNO düzeyi gruplarına göre ANOVA testi sonuçları

\begin{tabular}{|c|c|c|c|c|c|c|}
\hline \multicolumn{7}{|c|}{ ANOVA } \\
\hline \multicolumn{2}{|c|}{ Düşünme Stilleri } & Kareler Toplamı & Sd & Kareler Ortalaması & $\mathrm{F}$ & $\mathrm{p}$ \\
\hline & Gruplar Arası & 1,013 & 2 & ,506 & ,822 & ,443 \\
\hline \multirow[t]{3}{*}{ Yürütmeci } & Gruplar İçi & 50,515 & 82 & ,616 & & \\
\hline & Toplam & 51,528 & 84 & & & \\
\hline & Gruplar Arası & 4,116 & 2 & 2,058 & 1,818 & 169 \\
\hline \multirow[t]{3}{*}{ Yargılayıcı } & Gruplar İçi & 93,952 & 83 & 1,132 & & \\
\hline & Toplam & 98,068 & 85 & & & \\
\hline & Gruplar Arası & 1,784 & 2 & ,892 & ,853 & ,430 \\
\hline \multirow[t]{3}{*}{ Monarşik } & Gruplar İçi & 88,905 & 85 & 1,046 & & \\
\hline & Toplam & 90,689 & 87 & & & \\
\hline & Gruplar Arası & 3,488 & 2 & 1,744 & 1,491 & 231 \\
\hline \multirow[t]{3}{*}{ Hiyerarşik } & Gruplar İçi & 98,250 & 84 & 1,170 & & \\
\hline & Toplam & 101,739 & 86 & & & \\
\hline & Gruplar Arası & 3,862 & 2 & 1,931 & 1,962 & 147 \\
\hline \multirow[t]{3}{*}{ Oligarşik } & Gruplar İçi & 78,750 & 80 & 984 & & \\
\hline & Toplam & 82,612 & 82 & & & \\
\hline & Gruplar Arası & ,830 & 2 & ,415 & ,376 & 688 \\
\hline \multirow[t]{3}{*}{ Anarşik } & Gruplar İçi & 89,389 & 81 & 1,104 & & \\
\hline & Toplam & 90,219 & 83 & & & \\
\hline & Gruplar Arası & 1,603 & 2 & ,801 & ,753 & 474 \\
\hline \multirow[t]{3}{*}{ Bütünsel } & Gruplar İçi & 91,463 & 86 & 1,064 & & \\
\hline & Toplam & 93,066 & 88 & & & \\
\hline & Gruplar Arası & 1,728 & 2 & ,864 & ,757 & ,472 \\
\hline \multirow[t]{3}{*}{ Ayrıntisal } & Gruplar İçi & 97,054 & 85 & 1,142 & & \\
\hline & Toplam & 98,782 & 87 & & & \\
\hline & Gruplar Arası & 2,841 & 2 & 1,420 & ,855 & ,429 \\
\hline \multirow[t]{3}{*}{ İçsel } & Gruplar İçi & 134,500 & 81 & 1,660 & & \\
\hline & Toplam & 137,341 & 83 & & & \\
\hline & Gruplar Arası & 4,121 & 2 & 2,060 & 1,209 & 304 \\
\hline \multirow[t]{3}{*}{ Dışsal } & Gruplar İçi & 141,392 & 83 & 1,704 & & \\
\hline & Toplam & 145,513 & 85 & & & \\
\hline & Gruplar Arası & 1,138 & 2 & ,569 & ,629 & ,536 \\
\hline \multirow[t]{2}{*}{ Tutucu } & Gruplar İçi & 71,527 & 79 & ,905 & & \\
\hline & Toplam & 72,666 & 81 & & & \\
\hline
\end{tabular}

Tablo 10’a bakıldığında çalışma grubunun AGNO düzeyi değişkenine göre düşünme stillerinde anlamlı farklılıklara sahip olmadıkları görülmektedir. Homojenlik şartını sağlamayan Yasamacı düşünme stili alt boyutu için ANOVA yerine uygulanan Welch testi sonucuna göre de (Yasamacı $p=0,369>0,005$ ) gruplar arasında anlamlı fark olmadığı görülmüştür.

Çalışma grubunun bireysel çalgı değişkenine göre grup varyanslarının homojenliği testi bulguları Yürütmeci $(p=, 027)$, Oligarşik $(p=, 043)$, Bütünsel $(p=, 031)$, Ayrıntisal $(p=, 020)$ ve Dışsal $(p=, 015)$ düşünme stillerinin bireysel çalgı grup varyanslarının homojen olmadı̆̆ını $(p<0,05)$; diğer düşünme stillerinin grup varyanslarının homojen $(p>0,05)$ olduğunu göstermektedir.

Tablo 11. Düşünme stillerinin bireysel çalgı gruplarına göre ANOVA testi sonuçları

\begin{tabular}{|c|c|c|c|c|c|c|}
\hline \multicolumn{7}{|c|}{ ANOVA } \\
\hline & e Stilleri & Kareler Toplamı & $\mathrm{Sd}$ & Kareler Ortalaması & $\mathrm{F}$ & $p$ \\
\hline \multirow{3}{*}{ Yasamacı } & Gruplar Arası & 7,272 & 11 & ,661 & 1,035 & ,425 \\
\hline & Gruplar İçi & 46,620 & 73 & 639 & & \\
\hline & Toplam & 53,892 & 84 & & & \\
\hline \multirow{3}{*}{ Yargılayıcı } & Gruplar Arası & 21,103 & 11 & 1,918 & 1,876 & ,056 \\
\hline & Gruplar İçi & 76,684 & 75 & 1,022 & & \\
\hline & Toplam & 97,788 & 86 & & & \\
\hline
\end{tabular}




\begin{tabular}{|c|c|c|c|c|c|c|}
\hline \multicolumn{7}{|c|}{ ANOVA } \\
\hline \multicolumn{2}{|c|}{ Düşünme Stilleri } & Kareler Toplamı & $\mathrm{Sd}$ & Kareler Ortalaması & $\mathrm{F}$ & $p$ \\
\hline & Gruplar Arası & 8,012 & 11 & ,728 & 675 & 757 \\
\hline \multirow[t]{3}{*}{ Monarşik } & Gruplar İçi & 83,045 & 77 & 1,079 & & \\
\hline & Toplam & 91,057 & 88 & & & \\
\hline & Gruplar Arası & 13,909 & 11 & 1,264 & 1,082 & 387 \\
\hline \multirow[t]{3}{*}{ Hiyerarşik } & Gruplar İçi & 88,823 & 76 & 1,169 & & \\
\hline & Toplam & 102,732 & 87 & & & \\
\hline & Gruplar Arası & 21,529 & 11 & 1,957 & 2,068 & ,034* \\
\hline \multirow[t]{3}{*}{ Anarşik } & Gruplar İçi & 69,094 & 73 & ,946 & & \\
\hline & Toplam & 90,622 & 84 & & & \\
\hline & Gruplar Arası & 14,961 & 11 & 1,360 & ,802 & ,638 \\
\hline \multirow[t]{3}{*}{ İçsel } & Gruplar İçi & 123,813 & 73 & 1,696 & & \\
\hline & Toplam & 138,775 & 84 & & & \\
\hline & Gruplar Arası & 8,208 & 11 & ,746 & ,822 & 619 \\
\hline \multirow[t]{3}{*}{ Liberal } & Gruplar İçi & 64,467 & 71 & 908 & & \\
\hline & Toplam & 72,675 & 82 & & & \\
\hline & Gruplar Arası & 42,182 & 11 & 3,835 & 2,461 & $011^{*}$ \\
\hline \multirow[t]{2}{*}{ Tutucu } & Gruplar İçi & 116,878 & 75 & 1,558 & & \\
\hline & Toplam & 159,060 & 86 & & & \\
\hline
\end{tabular}

$* p<0.05$

Tablo 11 'de yer alan bulgulara bakıldığında çalışma grubunun bireysel çalgı değişkenine göre Anarşik $(F=2,068, p<$ .050) ve Tutucu $(F=2,461, p<.050)$ düşünme stillerinde anlamlı farklılıklara sahip olduğu görülmektedir. Homojenlik şartını sağlamayan Oligarşik, Bütünsel, Ayrıntısal ve Dışsal düşünme stili alt boyutları için ANOVA yerine uygulanan Welch testi sonuçlarına göre ise (Oligarşik $p=0,213>0,005$; Bütünsel $p=0,331>0,005$; Ayrıntısal $p=0,517>0,005$ ve Dışsal $p=0,279>0,005)$ gruplar arasında anlamlı fark olmadığı görülmüştür. Yürütmeci düşünme stili için gruplardan en az birinin sıfir varyansa sahip olması nedeniyle Welch testi uygulanamamıştr. Çalışma grubundan elde edilen bulgulara bakıldığında bireysel çalgı değişkenine göre düşünme stillerinde anlamlı farklılıklar olmadığı belirlenmiştir. Bu durum çalışma grubunda yer alan öğrencilerin düşünme stillerinin çaldıkları çalgıya bağlı olmadığı ya da çalgı seçimlerine etki etmediği şeklinde yorumlanabilir.

\section{Tartışma ve Sonuçlar}

Mesleki müzik eğitimi alan lisans öğrencilerinden oluşan çalışma grubunun genel olarak Yasamacı, Yürütmeci, Yargılayıcı, Hiyerarşik, Dışsal ve Liberal düşünme stillerine daha yüksek düzeyde sahip oldukları görülmüştür. Elde edilen bulgular literatürle de tutarlılık göstermektedir. Akbulut'un (2006), Buluş'un (2005) ve Dinçer'in (2009) çalışmalarında öğretmen adaylarının 1. Tip düşünme stilleri olarak da kavramsallaştrılan Yasama, Hiyerarşik, Yargı, Bütünsel, Dışsal ve Liberal düşünme stillerini sıklıkla tercih ettikleri görülmüştür. Bunun yanı sıra Tutucu, Oligarşik, Ayrıntısal ve Bütünsel düşünme stillerini en az düzeyde tercih ettikleri saptanmıştır. Buluş’a (2005) göre öğrencilerde var olan bu eğilim, zihinsel öz yönetim gerçekleştirilirken yapılan tercihler açısından pozitif bir durumdur. Bu araştrrmada elde edilen bulgular değerlendirildiğinde çalışma grubunun mesleki müzik eğitimi almalarına bağlı olarak, Yasamacı, Dışsal ve Liberal düşünme stillerinde gelişme olduğu düşünülebileceği gibi, bu düşünme stillerine sahip oldukları için mesleki müzik eğitimi almayı tercih ettikleri de düşünülebilir. Ayrıca mesleki müzik eğitiminin önemli unsurları olan çalgı çalma, yorumlama, besteleme, armoni vb. gibi uygulamalı pek çok alan dersinde yerine getirilmesi gereken görevler ve uyulması gereken kurallar öğrencilerin Hiyerarşik düşünme stilinde kendilerini geliştirmelerine de etki etmiş olabilir.

Düşünme stillerinin cinsiyet değişkenine göre fark gösterip göstermediğini belirlemek için yapılan analizler sonucunda, düşünme stilleri envanterinden elde edilen alt ölçek ortalamalarının, cinsiyete göre bazı farklılıklar göstermekle birlikte genelde orta düzeyin üzerinde olduğu belirlenmiştir. Kadınlarda en yüksek ortalama Monarşik düşünme stili alt boyutunda görülürken erkeklerde en yüksek ortalama Yasamacı düşünme stili alt boyutunda görülmüştür. Elde edilen sonuçlar yurtiçi literatürdeki diğer araştırmalarda elde edilen bazı sonuçlarla benzerlik bazı sonuçlarla da zıtlık göstermektedir. Zihinsel Öz Yönetim kuramına göre düşünme stilleri cinsiyete göre farklılık göstermektedir. Ancak bu farklılıklar kültürden de etkilenmektedir. Her kültürde kadınlar ve erkekler farklı değerlendirileceği için düşünme stilleri de kültürel cinsiyet algısı bağlamında ele alınmalıdır (Sternberg, 2009). Esmer (2013)'in çalışmasında kadınlar ile erkeklerin farklı düşünme stillerine sahip oldukları, erkeklerin Yasayapıcı, Oligarşik, Anarşik, Bütünsel ve Tutucu; 
kadınların ise Yürütmeci, Monarşik ve Hiyerarşik düşünme stillerine sahip oldukları tespit edilmiştir. Dinçer'in (2009) çalışmasında ise erkeklerin Tutucu ve Dışsal düşünme stillerine kadınlardan daha yüksek oranda sahip oldukları tespit edilmiştir. Bu durum düşünme stillerinde aynı kültür çatısı altında bile zamana bağlı olarak değişiklikler görülebileceği anlamına gelebilir. Bu araştırmada elde edilen sonuçlar, çalışma grubundaki kadınların bir işe odaklandıklarında başka işlerle ilgilenmedikleri, erkeklerin ise daha çok yeni fikirler üretme gibi işlerle ilgilendikleri şeklinde yorumlanabilir. Müziksel bağlamda düşünüldüğünde de erkeklerin kadınlara oranla daha çok besteleme, yorumlama gibi etkinlikler başta olmak üzere pek çok müzikal süreçte yeni fikirler, yeni uygulamalar üretmeyi, kendi kurallarını koymayı tercih ettikleri söylenebilir. Kadınların Liberal ve Yasamacı Düşünme Stili puanlarının erkeklere oranla daha düşük olması da bu durumu destekler niteliktedir.

Düşünme stillerinin sınıf düzeyine göre durumunu belirlemek için yapılan istatistik analizlerden elde edilen bulgular 2. sınıf öğrencilerinin Yasamacı düşünme stiline, 4. sınıf öğrencilerinin ise Yasamacı, Bütünsel ve Ayrıntısal düşünme stillerine daha yüksek düzeyde sahip olduklarını göstermiştir. Bir diğer deyişle müzik eğitimi almakta olan çalışma grubu öğrencilerinin eğitimlerinin sonuna yaklaşttkları 4. sınıf düzeyinde daha Yasamacı, Bütünsel ve Ayrıntısal düşünme stiline sahip oldukları söylenebilir. Bir sanatçı/müzisyen besteleme ve yorumlama gibi müziksel yaratıcılığın en belirgin olduğu etkinlikler sırasında her bir ayrıntıya odaklanabildiği gibi eserin bütün olarak müziksel estetik değeri yüksek bir biçimde nasıl duyulduğuna da önem verir. Bu noktada göz ardı edilmemesi gereken bir nokta da müzikle ilgili yaratııılığın yalnızca besteleme ve/veya yorumlama ile sınırlandırılamayacağıdır. Elbette ki müzik alanı içerisinde yer alan diğer konularda da (müzik teorisi, çalgı tekniği, armoni, müzik analizi vb.) pek çok yeni fikir ve uygulama üretimi söz konusu olabilir. Yeni bir teori üretirken de Yasamacı, Bütünsel ve Ayrıntısal düşünme stillerine sahip bireyler bu stile uygun şekilde çalışacaklardır. Bu bağlamda bakııdığında elde edilen bulgular son sınıf öğrencilerinin Yasamacı düşünme stiliyle birlikte Bütünsel ve Ayrıntısal düşünme stillerine de sahip olabilmelerini açıklayabilir.

Güzel Sanatlar Liseleri dışında kalan diğer liselerden mezun olan öğrencilerin Yasamacı, Yürütmeci, Yargılayıcı, Hiyerarşik ve Liberal düşünme stilleri puan ortalamalarının Güzel Sanatlar Liselerinden mezun olan öğrencilere göre daha yüksek olduğu görülmüştür. Güzel Sanatlar Liselerinde müzik sanatına ilişkin teknik eğitimin erken yaşta verilmesi nedeniyle bu öğrencilerin yükseköğretimde daha Yasamacı düşünmeleri beklenirken, diğer liselerden gelen öğrencilerin Yasamacı düşünme stili puanlarının yüksek olması şaşırtıcı görünmektedir. Bu durumun, diğer liselerde uygulanan eğitim programlarının bireylerin genel bilişsel becerilerini geliştirebilmelerine yönelik olmasından kaynaklandığı düşünülmektedir. Genel lise eğitimi alan öğrencilerin Yasamacı, Yargılayıcı, Yürütmeci ve Liberal düşünme stillerinin daha belirgin olması aldıkları eğitimin programlarında yer alan görevlerin ve problemlerin yargılayıcı, yürütmeci ve yenilikçi-yaratıcı çalışmalar yapmaya teşvik edici özelliğe sahip olmasından kaynaklandığı düşünülmektedir. Bir diğer açıdan bakıldığında hem Güzel Sanatlar Liselerinin hem de Güzel Sanatlar Liselerine kayıtlı öğrencilerin sayıları diğer liselere oranla azdır. Ek olarak diğer liselerden ayrı bir eğitim programı da uyguladıkları için Güzel Sanatlar Liselerinden gelen öğrencilerin başka (Yasamacı, Yürütmeci, Yargılayıcı ve Liberal düşünme stilleri dışında kalan) düşünme stillerine sahip olmaları doğal görünmektedir. Bu durum, Güzel Sanatlar Liselerinde öğrencilerin müziksel yaratıcılığa değil müzikal yetkinliğe (temel kavramları bilme, çalgıda temel teknik düzeyde yetkin olma vb.) odaklı bir eğitim almalarına bağlı olduğu şeklinde de yorumlanabilir. Bu konuda yapılacak olan yeni araştırmaların sonuçları konunun açıklanmasında daha etkili olacaktır.

Çalışma grubundan elde edilen bulgulara bakıldığında AGNO düzeyi ve bireysel çalgı değişkenlerine göre düşünme stillerinde anlamlı farklılıklar olmadığı belirlenmiştir. Bu durum çalışma grubunda yer alan öğrencilerin düşünme stillerinin çaldıkları çalgıya bağlı olmadığı ya da çalgı tercihlerine etki etmediği ve akademik başarı düzeyleriyle ilişkili olmadığı anlamına gelmektedir. Elde edilen bulgular kuramın genel ilkelerinden biri olan, düşünme stillerinin değişik kültürlere göre farkılık gösterebileceği ilkesi bağlamında değerlendirildiğinde Buluş'un (2006) çalışmasında elde edilen bulgularla benzerlik göstermektedir. Buluş'a (2006) göre Türkiye'de uygulanan geleneksel eğitim sistemine bağlı olarak öğrencilerin düşünme stillerinde akademik başarı açısından anlamlı bir fark bulunmamaktadır. Bireysel çalgı değişkenine göre bakıldığında ise öğrencilerin düşünme stilleri arasında farkın olmayışı Akbulut'un (2006) çalışmasında elde edilen sonuçlarla benzerlik göstermektedir. Ancak elde edilen bu sonuçlar literatürde yer alan bazı çalışmalarla da örtüşmemektedir. Cano-García ve Hughes'un (2000) çalışmasında bireysel çalışmayı tercih eden (içssel); problem çözümü için yaratmayı, formülleştirmeyi ve planlamayı sevmeyen (olumsuz anlamda Yasamacı) ve mevcut kurallara bağlı olan (Yürütmeci) öğrencilerin daha yüksek akademik başarıya sahip oldukları tespit edilmiştir. Zhang'in (2005) çalışmasında fizik öğretimi bağlamında kombine (birleşik) stilleri tercih eden öğrencilerin, tek bir stili tercih eden öğrencilere kıyasla daha başarılı oldukları tespit edilmiştir. Hatta tek stili tercih eden öğrencilerin tercih ettikleri stilde bile kombine stilleri tercih eden öğrencilerin daha başarılı oldukları görülmüştür. Buluş'un (2005) yaptı̆ı araştırmada, örneklem genelinde Yasama, dördüncü sınıflarda Hiyerarşik düşünme stilleri ile akademik başarı arasında pozitif ilişkiler bulunurken, yine örneklem genelinde Dışsal ve Tutucu, birinci sınıflarda ise Ayrıntısal ve Tutucu düşünme stilleri ile akademik başarı ara-

| Kastamonu Eğitim Dergisi, 27(2), 2019| 
sında negatif ilişkiler bulunmuştur. Düşünme stilleri kuramına göre stil tercihleri kültüre, göreve, yaşa, cinsiyete göre değişiklik gösterebilir (Sternberg, 1997 ve 2009). Bu bağlamda bakıldığında elde edilen sonuçların başka kültürlerde yapılan çalışmalarla çelişmesi doğal görünmektedir. Buna karşın diğer çalışmalardan farklı olan bu çalışmanın sonuçları kuramın genel değerlendirmesiyle tutarlıdır.

\section{5. Öneriler}

Genel olarak bakıldığında mesleki müzik eğitimi alan üniversite öğrencilerinden oluşan çalışma grubunun akademik başarı düzeylerinden ve bireysel çalgılarından bağımsız şekilde Yasamacı, Yürütmeci, Yargılayıcı, Hiyerarşik, Dışsal ve Liberal düşünme stillerine sahip oldukları görülmüştür. Çünkü bireylerin stillerden oluşan bir profili vardır ve bu profilin bileşenleri duruma, cinsiyete, yaşa, kültüre göre değişiklik gösterir (Sternberg, 1988, 1997 ve 2009). Mesleki müzik eğitiminin doğal bir getirisi olarak eğitim süreci ilerledikçe öğrencilerin edindikleri beceriler ve geliștirdikleri müziksel beceriler, özellikle Yasamacı, Yargılayıcı ve Liberal düşünme stillerinde kendilerini geliștirmelerine yol açmış olabilir. Mesleki müzik eğitiminin düşünme stilleri üzerindeki etkileri bu çalışma kapsamında ele alınmadığı için bu bir varsayımdan ibarettir ancak yapılacak olan yeni çalışmalar bu konunun aydınlanmasında önemli yer tutabilir. Ayrıca benzer çalışmaların Güzel Sanatlar Liselerindeki öğrenciler, müzik öğretmeni adayları, müzik öğretmenleri, profesyonel/yarı profesyonel/amatör müzisyenler ve müzik eğitimi almamış kişilerden oluşan daha geniş katılımcı kitlesine ulaşılarak yapılması düşünme stilleri ile müzik ilişkisinin daha iyi açıklanabilmesi konusunda yararlı olabilir.

\section{Kaynakça}

Akbulut, E. (2006). Pamukkale Üniversitesi Eğitim Fakültesi Müzik Eğitimi Anabilim Dalı öğrencilerinin düşünme stil profilleri çerçevesinde değerlendirilmesi. Ulusal Müzik Eğitimi Sempozyumu Bildirisi (s. 510-528). Denizli: Pamukkale Üniversitesi Eğtitim Fakültesi.

Alborzi, S., \& Ostovar, S. (2007). Thinking styles of gifted and nongifted students in Iran. Psychological Reports, 100, 1076-1082.

Başol, G., \& Türkoğlu, E. (2009). Sınıf öğretmeni adaylarının düşünme stilleri ile kontrol odağı durumları arasındaki ilişki. Uluslararası Insan Bilimleri Dergisi, 6(1), 737-757.

Bibak, F. (2016). Comparing the thinking styles and learning styles among the gifted and ordinary female senior high school students (Natural sciences and Mathematics) for the year 2011-2012. World Essays Journal, 4(1), 40-44.

Buluş, M. (2005). İlköğretim bölümü öğrencilerinin düşünme stilleri profili açısından incelenmesi. Ege Eğitim Dergisi, 6(1), 1-24.

Buluş, M. (2006). Assesment of thinking styles inventory, academic achievement and student teacher's characteristics. Eğitim ve Bilim, 31(139), 35-48.

Cambridge Learner's Dictionary. (2007). Cambridge, UK: Cambridge University Press.

Cano-García, F., \& Hughes, E. H. (2000). Learning and thinking styles: an analysis of their interrelationship and influence on academic achievement. Educational Psychology, 20(4), 413-430.

Dai, D. Y., \& Feldhusen, J. F. (1999). A validation study of the thinking syles inventory: Implication for gifted education. Roeper Review, 21(4), 302-307.

Demirel, Ö. (2014). Öğretim ilke ve yöntemleri, öğretme sanat (20. basım). Ankara: Pegem Akademi.

Dinçer, B. (2009). Öğretmen Adaylarının Düşünme Stilleri Profillerinin Çeşitli Değişkenler Açısından Değerlendirilmesi. (Yayımlanmamış Yüksek Lisans Tezi). Adnan Menderes Üniversitesi Sosyal Bilimler Enstitüsü Eğitim Bilimleri Anabilim Dalı, Aydın.

Durmuş, B., Yurtkoru, E. S., \& Çinko, M. (2016). Sosyal bilimlerde SPSS'le veri analizi (6. basım). İstanbul: Beta.

Esmer, E. (2013). Öğretmen Adaylarının Zihinsel Stil Tercihlerinin (Düşünme Stillerinin) Incelenmesi. (Yayımlanmamış Doktora Tezi). Yıldız Teknik Üniversitesi Sosyal Bilimler Enstitüsü Eğitim Bilimleri Anabilim Dalı Eğitim Programları ve Öğretim Programı, İstanbul.

Fer, S. (2005). Düşünme stilleri envanterinin geçerlik ve güvenirlik çalışması. Kuram ve Uygulamada Eğitim Bilimleri, 5(1), 31-68.

Güven, B. (2013). Öğretim ilke ve yöntemleriyle ilgili temel kavramlar. Ş. Tan, (Ed.) Öğretim ilke ve yöntemleri içinde, (s. 1-34). Ankara: Pegem Akademi.

Özbek Baştuğ, Ö. Y., \& Çelik, B. (2014). Thinking styles of teachers, principals and inspectors. Educational Research and Reviews, 9(21), 1173-184.

Özdamar, K. (2009). Paket programlar ile istatistiksel veri analizi (7. basım). Eskişehir: Kaan Kitabevi.

Park, S. K., Park, K. H., \& Choe, H. S. (2005). The relationship between thinkink styles and scientific giftedness in Korea. The Journal of Secondary Gifted Education, 2(3), 87-97.

Schunk, D. H. (2011). Öğrenme: Giriş, sorunlar ve tarihsel bakış açıları. D. H. Schunk (Ed.) Learning theories an educational perspective/ Eğitimsel bir bakışla öğrenme teorileri (Çev. M. Y. Demir, 2. basım, s. 1-26) içinde. Ankara: Nobel Akademik. (Orijinal ilk baskı 1991).

Sternberg, R. J. (1988). Mental Self-Government: A theory of intellectual styles and their development. Human Development 31, $197-224$. Sternberg, R. J. (1997). Thinking styles. New York, USA: Cambrige University Press. 
Sternberg, R. J. (2009). Düşünme stilleri. (Çev. E. Güngör) İstanbul: SEV Matbaacılık ve Yayıncılık.

Sternberg, R. J., \& Grigorenko, E. L. (1997). Are cognitive styles still in style? American Psychologist, 52(7), 700-712.

Sternberg, R. J., \& Wagner, R. K. (1991). MSG Thinking style inventory. Yayımlanmamış El Kitabı.

Stil. (Tarihsiz). Güncel Türkçe sözlük online içinde. Tük Dil Kurumu. http://www.tdk.gov.tr/index.php?option=com_gts\&arama=gts\&guid=TDK.GTS.582ee9dd5e50b2.60052982 adresinden alındı

Tüzer, L. (2016). Sını öğretmenlerinin düşünme stillerinin çeşitli değişkenler açısından incelenmesi. (Yayımlanmamış Yüksek Lisans Tezi). Kahramanmaraş Sütçü İmam Üniversitesi Sosyal Bilimler Enstitüsü Eğitim Bilimleri Anabilim Dalı, Kahramanmaraş.

Valencia, M. N. (2007). Student-teacher thinking styles congruenceand academic achievement of Flipino high school students. Philippine Journal of Psychology, 40(1), 26-41.

Webster. (1993). The new Lexicon Webster's Encyclopedic dictionary of the English language. Lexicon.

Zhang, L. F. (1999). Further cross-cultural validation of the theory of mental self-government. The Journal of Psychology, $133(2), 165-181$.

Zhang, L. F. (2000a). Are thinking styles and personality types related? Educational Psychology, 20(3), 271-283.

Zhang, L. F. (2000b). Relationship between thinking styles inventory and study process questionanaire. Personality and Individual Differences, $29,841-856$.

Zhang, L. F. (2002). Measuring thinking styles in addition to measuring personality traits? Personality and Individual Differences, 33, 445458.

Zhang, L. F. (2003). Are parents' and children's thinking styles related? Psychological Reports, 93, 617-630.

Zhang, L. F. (2004). Do university students' thinking syles matter in their preferred teaching approaches? Personality and Individual Differences, 37, 1551-1564.

Zhang, L. F. (2005). Does teaching for a balanced use of thinking styles enhances students' achievement? Personality and Individual Differences, 38, 1135-1147.

Zhang, L. F. (2009). Anxiety and thinking styles. Personality and Individual Differences, 47, 347-351.

Zhang, L. F., \& Sachs, J. (1997). Assessing thinking styles in the theory of mental self-government: A Honk Kong validity study. Psychological Reports, 81, 915-928.

Zhang, L. F., \& Sternberg, R. J. (2000). Are learning approaches and thinking styles related? a study in two chinese populations. The Journal of Psychology, 134(5), 469-489.

Zhang, L. F., \& Sternberg, R. J. (2002). Thinking styles and teachers' characteristics. International Journal of Psychology, 37(1), 3-12.

Zhang, L. F., \& Sternberg, R. J. (2005). A threefold model of intellectual styles. Educational Psychology Review, 17(1), 1-53.

Zhang, L. F., \& Sternberg, R. J. (2006). The nature of intellectual styles. New Jersey, Mahwah, USA: Lawrence Erlbaum Associates. 